\title{
THE CURRENT DISTRIBUTION IN POLAND OF SOME EUROPEAN NEOPHYTIC BRYOPHYTES WITH SUPPOSED INVASIVE TENDENCIES
}

\author{
EWA FUdALI ${ }^{1}$, MIROSŁAW SZCZEPAŃSKI ${ }^{2}$, ANNA RUSIŃSKA ${ }^{3}$, \\ STANISŁAW ROSADZIŃSKI ${ }^{4}$, GRZEGORZ WOLSKI ${ }^{5}$ \\ ${ }^{1}$ Wrocław University of Life and Environmental Sciences, \\ Department of Botany and Plant Ecology \\ pl. Grunwaldzki 24a, 50-363 Wrocław, Poland \\ e-mail: ewa.fudali@up.wroc.pl \\ 2 Welski Landscape Park \\ Jeleń 84, 13-230 Lidzbark, Poland \\ ${ }^{3}$ Adam Mickiewicz University, Faculty of Botany, \\ Natural History Collections \\ Umultowska 89, 61-614 Poznań, Poland \\ ${ }^{4}$ Adam Mickiewicz University, \\ Department of Plant Ecology and Environmental Protection \\ Umultowska 89, 61-614 Poznań, Poland \\ 5 Łódź University, Department of Geobotany and Plant Ecology \\ Banacha 12/16, 90-237 Łódź, Poland
}

(Received: June 5, 2008. Accepted: October 4, 2008)

\begin{abstract}
The paper presents a brief review of published so far and recently recorded unpublished bryological data concerning the distribution in Poland of two neophytic (sensu Meusel 1943) mosses: Campylopus introflexus (Hedw.) Brid. and Orthodontium lineare Schwaegr. to estimate their current influence on native bryoflora. The data clearly indicate the constant spreading of these species towards the east, however, there is no direct evidence that they have been limiting the occurrence of native moss species. They are acidophilous species, so the acidification of the environment probably promotes their expansion. Maps of the most current distribution of Campylopus introflexus and Orthodontium lineare in Poland (in a system of ATMOS-grid squares) are provided, as well as a description of the first locality in Poland of another European bryo-neophyte species Leptophascum leptophyllum Mull. Hal.
\end{abstract}

KEY WORDS: invasive bryophytes, Campylopus introflexus, Orthodontium lineare, Leptophascum leptophyllum, bryophyte distribution in Poland, threats for bryophyte diversity.

\section{INTRODUCTION}

Nowadays biological invasions are considered to be one of the main topics in the fields of ecology, phytogeography and taxonomy. As it was remarked by Tokarska-Guzik (2005) the development manifested itself among others through trade, transport and tourism intensification resulted in enormous increase of introductions, both intended and casual. The influence of alien plants on native vegetation seems to be a serious threat for biodiversity in global scale. According to the quoted author the recognition of threats brought by invading aliens to the Polish native vegetation is still insufficient.
The aim of study was to analyze the current spreading of neophytic bryophytes (sensu Meusel 1943) in Poland and to attempt to estimate their influence on native bryoflora. Although numerous new localities of Orthodontium lineare Schwaegr. and Campylopus introflexus (Hedw.) Brid. have been recorded in our country in the last years (many of them not published yet - see: Table 1) these species' impact upon native bryoflora has not been discussed so far. The paper provides the most current distribution maps of these species in Poland (Figs 1 and 2). 


\section{EUROPEAN BRYO-NEOPHYTES AND THEIR CURRENT DISTRIBUTION IN POLAND}

European bryophyte flora is hardly affected by the process of anthropogenic changes (i.e. encroachment and establishment of aliens), brought about by wide geographical ranges of holarctic mosses. Söderström (1992) gives 22 species which are considered as 20th century bryological immigrants on European continent, only few of them however have managed to spread widely. In Poland have been recorded so far: Orthodontium lineare Schwaegr. (Ochyra 1982) and Campylopus introflexus (Hedw.) Brid. (Lisowski, Urbański 1989), originating from antipodes and the recently found subtropical Leptophascum leptophyllum (Mull. Hall.) J. Guerra \& M.J. Cano (Szczepański - unpublished).

First observations of these species in Europe came from Britain: Orthodontium lineare was recorded for the first time in 1911 close to Manchester, Campylopus introflexus in 1941 in Sussex (after Ochyra 1983), Leptophascum leptophyllum - in 1965 (Frahm 2002). Their further expansion on the European continent followed probably along the coast of France, Belgium and Holland (Söderström 1992; Hassel and Söderström 2005). The presence of Leptophascum leptophyllum on the continent was not documented until 1988 in Germany (Frahm 2002).

Orthodontium lineare and Campylopus introflexus are widely spread in the Western and Central Europe from France and Germany to the Czech Republic, Poland and Scandinavia (Ochyra 1983; Berg, Meinunger 1989; Söderström 1992). These species show tendencies to expand towards the east (Rasgulyaeva et al. 2001). The distribution of Leptophascum leptophyllum on the continent is still hardly documented and most localities of this moss come from Germany.

Orthodontium lineare establishes itself both in secondary forests and in natural communities. It grows on decaying wood and at the feet of trees with acid bark (pines, oaks). It is also quite frequently found on mineralized peat and on sandstones in the mountains (Herben 1987; Söderström 1992). It usually produces sporogons with a great number of spores. The Central European bryologists gave it a nickname of "bryological weed" because of its strong tendencies to colonize all available substrata. As Herben claims $(1990,1994)$, it supersedes other species from their habitats. Hedenäs et al. (1989), who studied the spreading of Orthodontium lineare in Sweden, claim that the species has low neophytic tendencies and does not replace other species.

The first record of Orthodontium lineare in Poland came from Mierzeja Helska (Ochyra 1982). The moss is currently widespread in western and central Poland, especially along the coast and northern lakelands. Most records come from Wielkopolska, Lower and Upper Silesia and Western Pomerania (Berdowski and Piszczek 1991; Fudali 1993, 1996, 1999; Gos L. and Gos K. 1993; Rusińska and Urbański 1993; Stefanek and Urbański 1993; Stebel 1994, 1997, 2002; Mindur 1998; Fojcik and Stebel 2001; Konstanciak 2002; Rusińska 2003; Górski and Urbański 2004; Bednorz et al. 2004; Stebel et al. 2005). A few years ago it was noted, yet low in abundance, in central part of the country (Wolski-unpublished), in south-eastern Poland (Podkarpacie and Pogórze Dynowskie, Armata 2005) and in Eastern
Pomerania (Pojezierze Chełmińsko-Dobrzyńskie, Szczepański 2007). In ATMOS squares grid system it covers 83 squares (Fig. 1).

From an ecological point of view, these localities are similar to those noted in other European countries. The species was observed mostly at the bases of trees (most frequently of pines and oaks which are tree species occupied only by few native epiphytic bryophytes) and on decaying wood, mainly in deciduous or mixed forests of rather natural character. Although it has a great number of localities, nothing indicates that the presence of that species has negatively influenced the epixylic or epiphytic communities of bryophytes in which it appeared. The moss always occurred in small turfs. It seems the species has utilized microhabitats' gaps within forest ecosystems and filled them.

Campylopus introflexus is regarded as an aggressive invader (Söderström 1992). Similarly to the previous species it frequently produces sporogons with many spores. Moreover, it spreads through fragments of stems, which helps to make big cushions and to expand on new territories.

All European localities of this moss are ecologically very similar. It grows on sandy edges of forest roads in pine or in mixed oak-pine forests, as well as in young pine plantations and heath-lands; less frequently Campylopus introflexus was recorded on dried peat (Frahm 1984; Berg 1985).

In Poland the first specimens were collected in 1986 in Wielkopolska (Pojezierze Sierakowskie - Lisowski and Urbański 1989). Afterwards it has been found in Western Pomerania (Gos 1991; Fudali 1992; Rusińska and Urbański 1993; Urbański 1994), Wzniesienia Gubińskie (Fojcik 1998) and Bory Dolnośląskie (Stefańska et al. 2006), as well as in southern Poland: Wyżyna Śląska (Stebel 1994, 1997; Fojcik and Stebel 2001; Stebel and Fojcik 2005) and Wyżyna Krakowsko-Częstochowska (Stebel and Fojcik 2005), Beskid Wysoki (Stebel and Fojcik 2005). It has also been noted, however in few places, in south-eastern Poland: Beskid Mały (Stebel 1995), Kotlina Sandomierska (Fojcik and Gumieniak 1999, Pogórze Dynowskie (Armata 2005). Recently the moss has also been recorded in Pojezierze Chełmińsko-Dobrzyńskie (Szczepański - unpublished) and in Mazowsze region (Wolski - unpublished). There have been no observations so far from north-eastern Poland. To the date published localities of Campylopus introflexus cover 67 squares of ATMOS grid system (Fig. 2). In some of its western localities the moss covered quite big surfaces, of about 3-4 square meters. It seems that the species colonizes mainly disturbed habitats and ecosystems; it was noted mostly at the edges of pine plantations, on the road sides in coniferous forests, frequently in pine stands growing on the acidophilous oak forests' habitat. In such places only few common native species can grow: e.g. $D i$ cranum scoparium and Ceratodon purpureus.

Leptophascum leptophyllum was the last discovered neophytic invasive species in Europe (Frahm 2002). It grows frequently in warm open habitats, mostly of anthropogenic character. It was noted in xerothermic habitats and on fields, fallow grounds and even on walls. In Europe it is sterile, so new areas are probably colonized by fragments of leaves easily spread by wind (Oesau 2002). Its distribution is fostered by agriculture which promotes spreading rhizoids and pieces of leaves in the fields.

This subtropical moss was noted in Poland for the first time by M. Szczepański in spring 2007 in Pojezierze Cheł- 


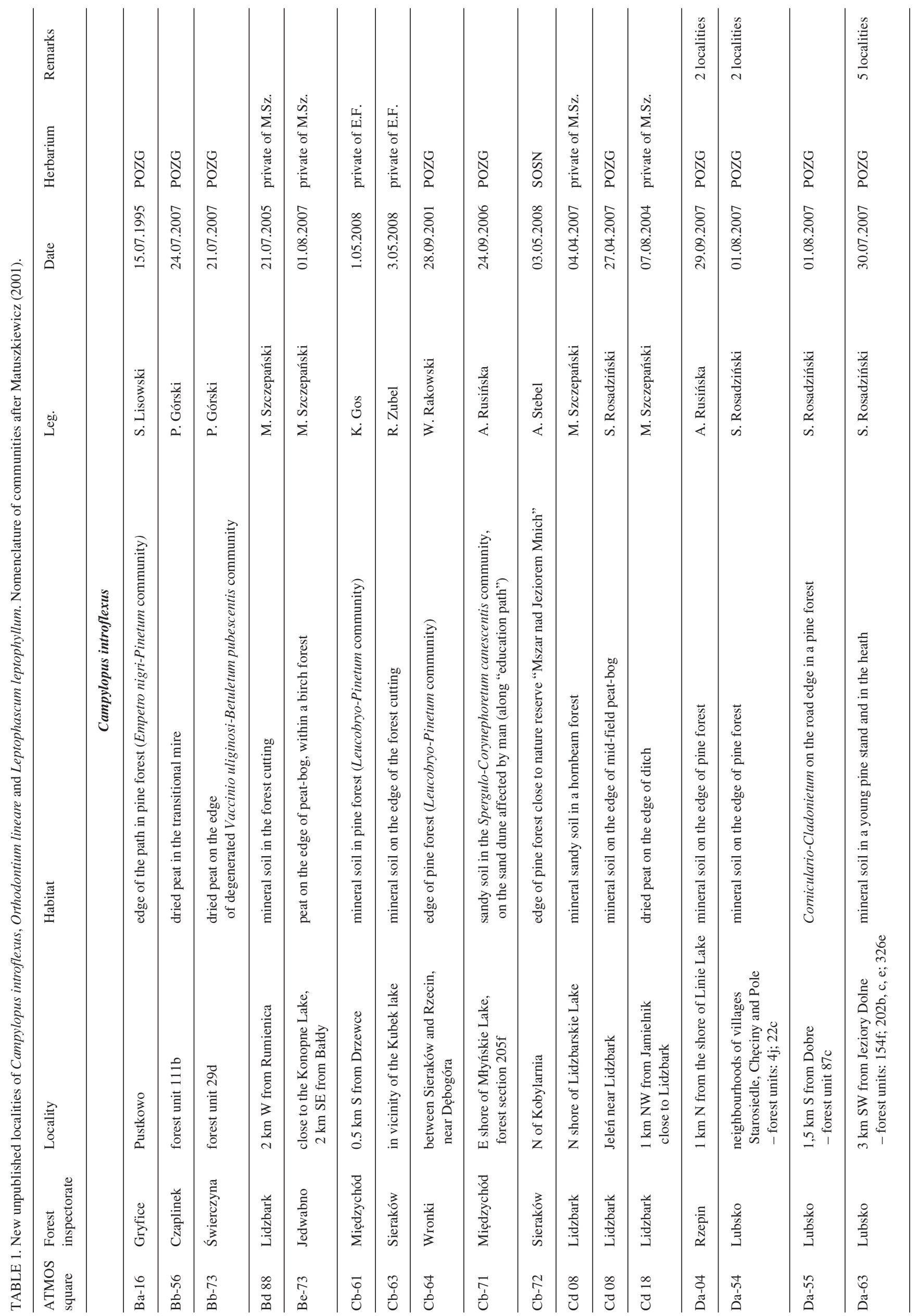




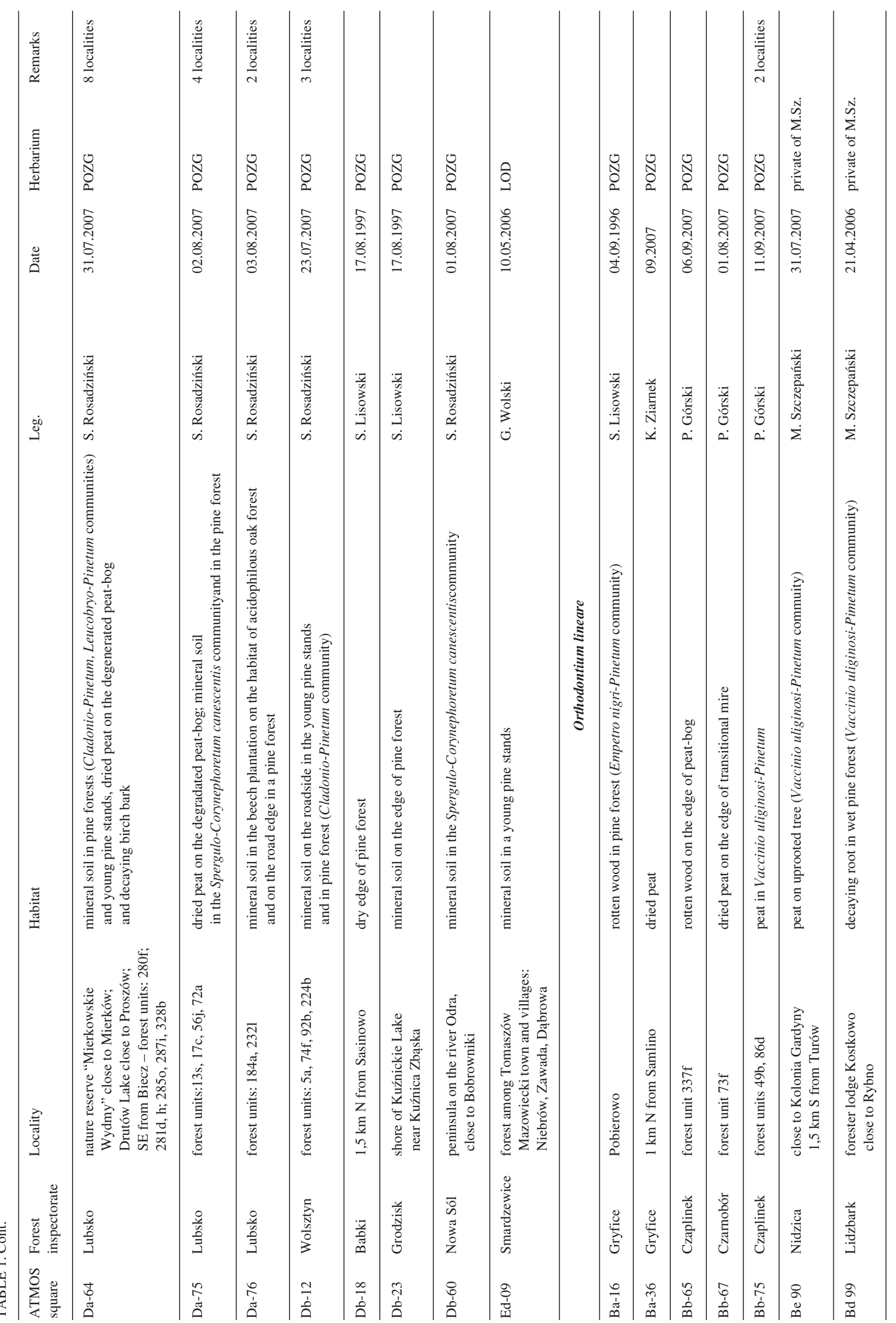




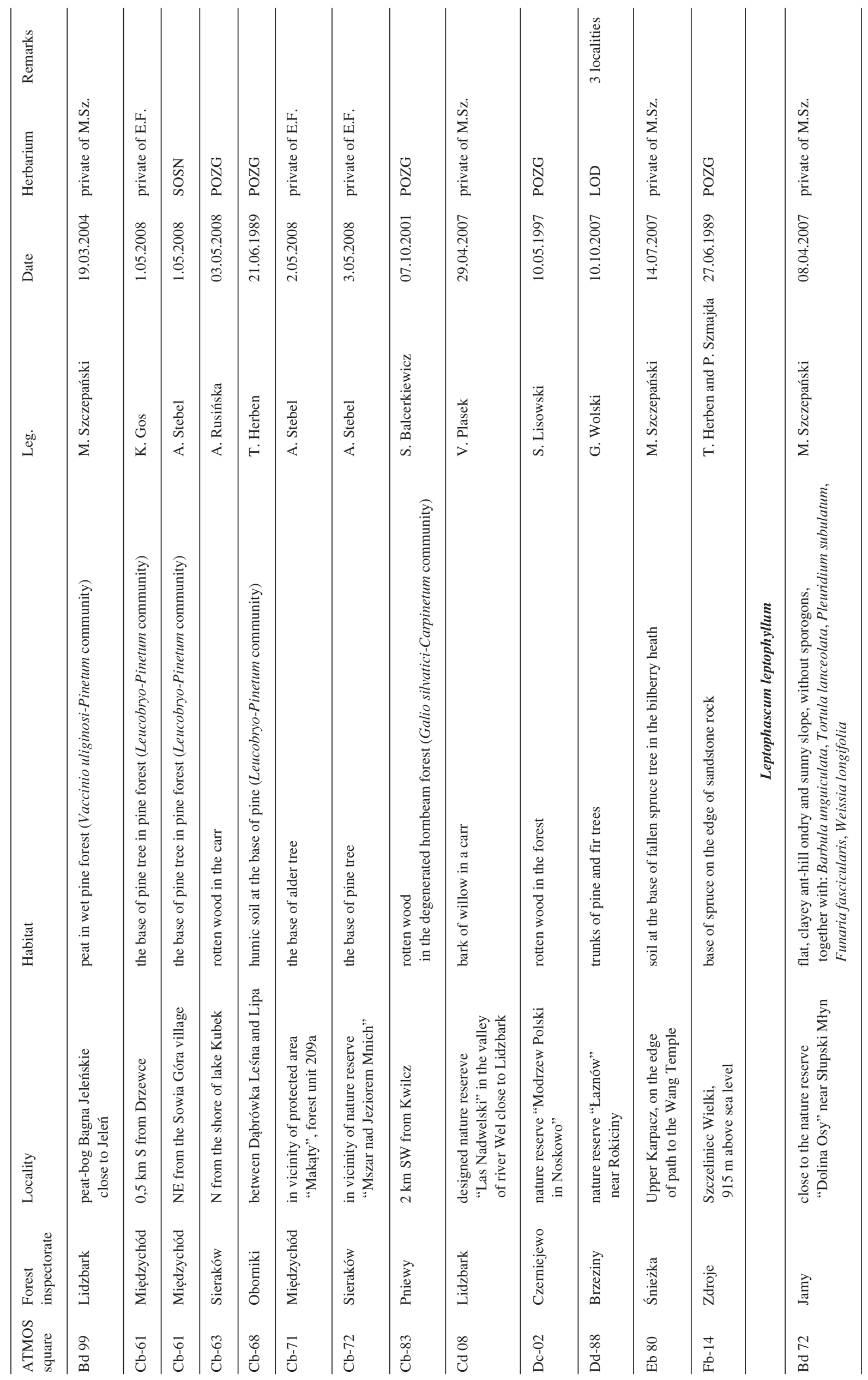




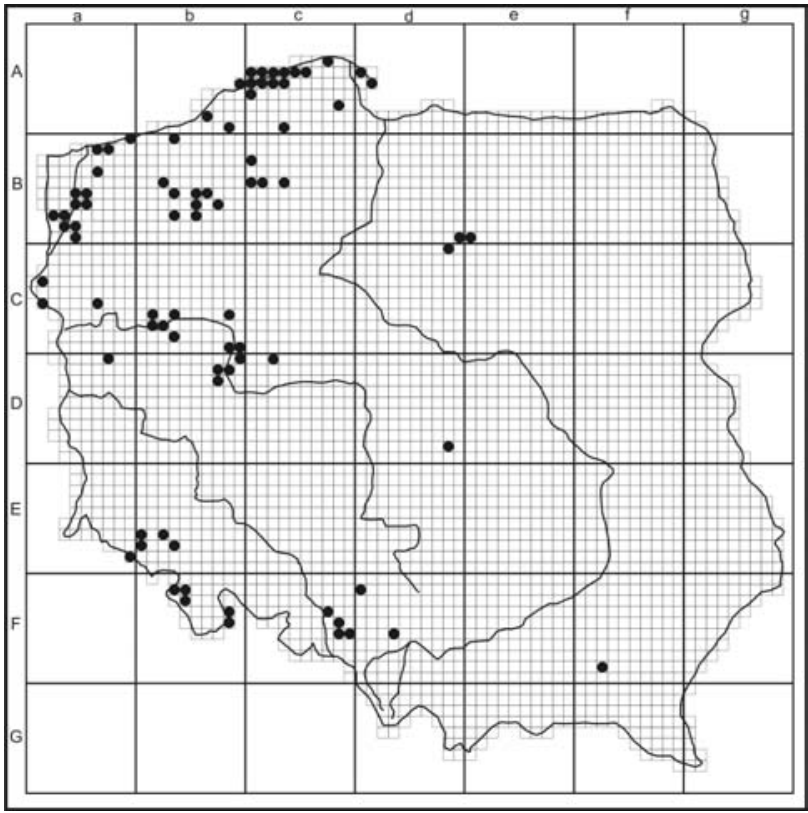

Fig. 1. Current distribution of Orthodontium lineare Schwaegr. in Poland (based both on published so far literature data and the author's recent records and material from herbaria not published yet - see: Table 1).

mińsko-Dobrzyńskie, on an ant-hill. It was noted once only (Fig. 3). The nearest locality of the moos is situated on the western bank of the Odra River (Frahm 2002). Probably it has migrated through the northern lakeland areas.

The ephemeral character of the bryophytes occurring in the fields may be one of the reasons of poor knowledge of the actual distribution of this species in Poland. Moreover, Leptophascum leptophyllum can be mistaken with common Tortula truncata, which grows in similar microhabitats.

\section{CONCLUSIONS}

Data concerning the current distribution of the two bryoneophytes Orthodontium lineare and Campylopus introfle-

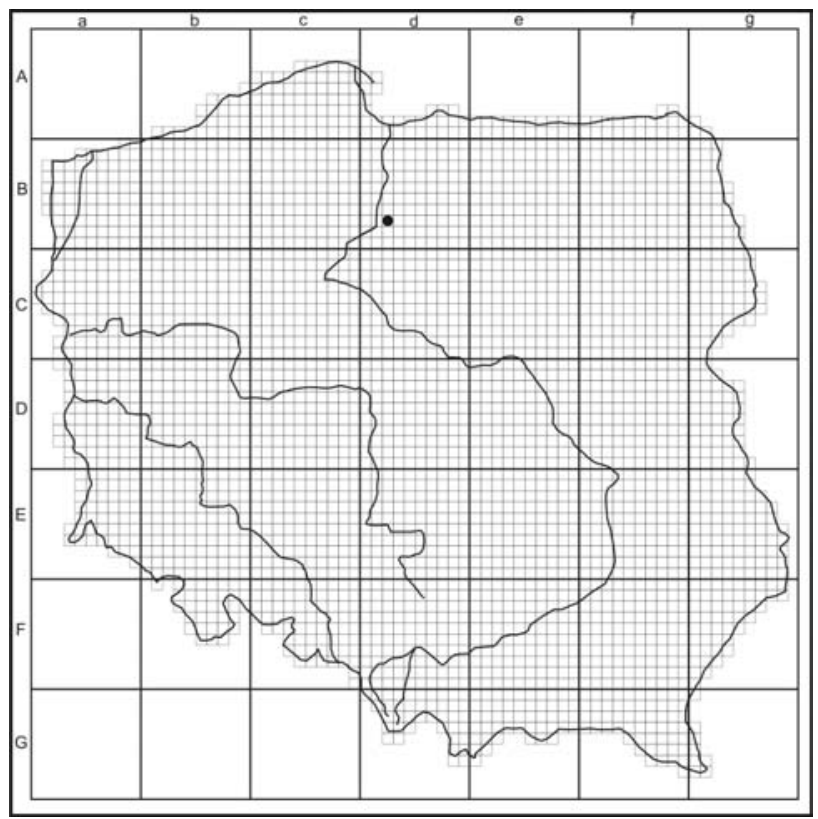

Fig. 3. The first locality of Leptophascum leptophyllum Mull. Hal. in Poland (found by M. Szczepański).

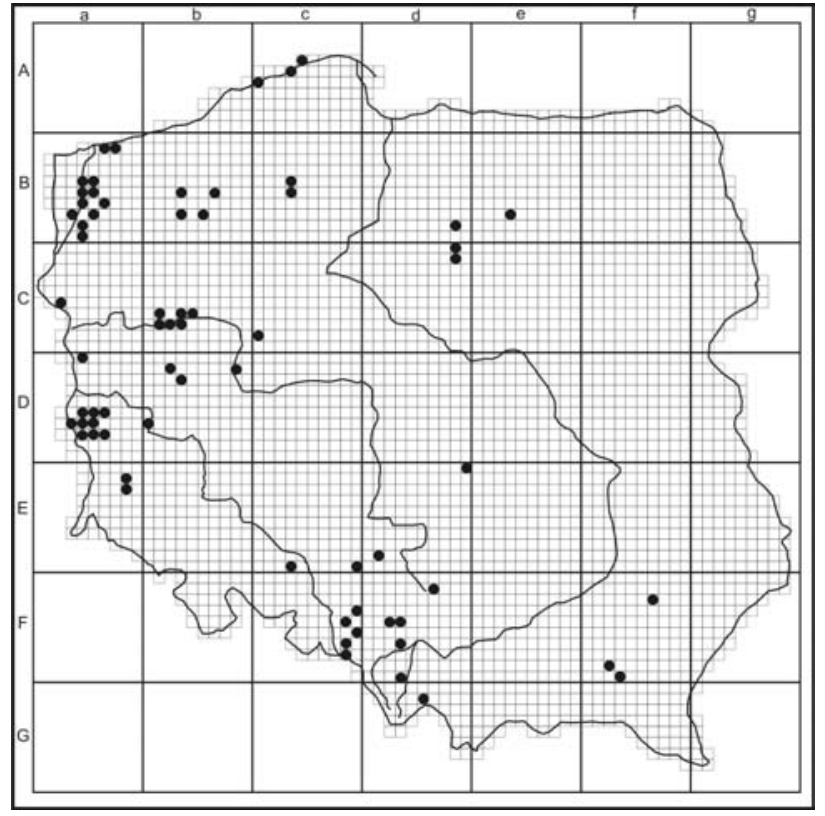

Fig. 2. Current distribution of Campylopus introflexus (Hedw.) Brid. in Poland (based both on published so far literature data and the author's recent records and material from herbaria not published yet - see: Table 1).

xus in Poland clearly indicate their constant spreading towards the east, it seems however that they have migrated to the Polish territory both from the west (Germany) and south (Czech Republic). They are acidophilous species and the acidification of the environment probably promotes their expansion. Compiled data suggest the species still colonize and establish themselves on the country area, but in the western part they could have entered upon a new, more advanced phase of invasion, the expansion stage. However, it should be kept in mind that the eastern part of Poland is still under-investigated bryologically. There is no direct evidence that the species have been limiting the occurrence of native moss species.

The recognition of the actual distribution of Leptophascum leptophyllum needs further detailed studies.

\section{ACKNOWLEDGEMENTS}

We warmly thank Prof. Dr hab. Maria Wojterska for improving the English text.

\section{LITERATURE CITED}

ARMATA L. 2005. A contribution to the bryoflora of the Pogórze Dynowskie (Foothills of Western Carpathians). Annales Univ. Mariae Curie-Skłodowska, Lublin - Polonia, Sectio C, 60: 101-111.

BEDNORZ L., KLIMKO M., MACIOROWSKI G., ANTKOWIAK W., JANYSZEK S., GÓRSKI P., URBAŃSKI P. 2004. Walory przyrodnicze rezerwatu "Kolno Międzychodzkie" ("Nature reserve "Kolno Międzychodzkie"). Roczn. AR Pozn. 363, Bot. 7: 3-10. (in Polish)

BERDOWSKI W., PISZCZEK M. 1991. Flora mchów południowej części Gór Złotych (Mosses of the southern part of Góry Złote Mts). Acta Univ. Wratislav. 1225 Pr. Bot. 45: 3-29. (in Polish with English summary)

BERG C. 1985. Zur Ökologie der neophytischen laubmossart Campylopus introflexus (Hedw.) Brid. in Mecklemburg. "Arch. Freund. Naturg. Mecklemburg" 25: 117-126. 
BERG C., MEINUNGER L. 1989. Neophytic bryophytes in the German Democratic Republic. In: T. Herben, C.B. Mc Queen (eds). Proceedings of the Sixth Meeting of CEBWG, Liblice, Czechoslovakia, 12-16th September, 1988, pp. 103-107. Botanical Institute of the Czechoslovak Academy of Sciences, Průhonice.

FOJCIK B. 1998. Stanowiska Campylopus introflexus (Musci, Dicranaceae) w rejonie Wzniesień Gubińskich (Pojezierza Wielkopolskie) ("Localities of Campylopus introflexus (Musci, Dicranacae) in the region of Wzniesienia Gubińskie hills (Wielkopolska Lakeland)"). Fragm. Flor. Geobot. Ser. Polonica 5: 303-305. (in Polish)

FOJCIK B. 1999. Mosses of the Wieluń Upland (Southern Poland). Fragm. Flor. Geobot 44(1): 77-128.

FOJCIK B., GUMIENIAK A. 1999. Stanowisko Campylopus introflexus (Musci, Dicranaceae) na Płaskowyżu Kolbuszowskim (Wyżyna Sandomierska) ("Locality of Campylopus introflexus (Musci, Dicranacae) in the region of Płaskowyże Kolbuszowskie (Sandomierz Upland)"). Fragm. Flor. Geobot. Ser. Polonica 6: 288-290. (in Polish)

FOJCIK B., STEBEL A. 2001. Struktura ekologiczna i przestrzenna brioflory miasta Katowice (Ecological and spatial structure of the Katowice town bryoflora). Materiały i opracowania Centrum Dziedzictwa Przyrody Górnego Śląska w Katowicach 5: 1-128. (in Polish with English summary)

FRAHM J.-P. 1984. Phytogeography of European Campylopus species. In: J. Váńa (ed.) Proceedings of the Third Meeting of CEBWG, Praha, Czechoslovakia, June 1982, pp. 191-212. Universita Karlova, Praha.

FRAHM J.-P. 2002. Zur aktuellen Verbreitung von Phascum leptophyllum in Deutschland. Bryologishe Rundbriefe 55: 1.

FUDALI E. 1992. Further spreading of Campylopus introflexus (Hedw.) Brid. (Musci, Dicranaceae) in Poland. Fragm. Flor. Geobot. 37(2): 503-506.

FUDALI E. 1993. Current distribution of Orthodontium lineare (Musci, Bryaceae) in Poland. Fragm. Flor. Geobot. 38(1): 159-162.

FUDALI E. 1996. Distribution of bryophytes in various urban-use complexes of Szczecin. Fragm. Flor. Geobot. 41(2): 717-745.

FUDALI E. 1999. Mszaki rezerwatów leśnych Puszczy Bukowej pod Szczecinem na tle zróżnicowania fitosocjologicznego i ekologicznego siedlisk (Bryophytes of the forest reserves of the beech forest near Szczecin in relation to the phytosociological and ecological diversity of habitats). Bad. Fizjogr. Pol. Zach., Ser. B. Botanika 48:187-201. (in Polish with English summary)

GOS L. 1991. Nowe stanowiska Campylopus introflexus (Musci, Dicranaceae) w Polsce (New localities of Campylopus introflexus (Musci, Dicranaceae) in Poland). Fragm. Flor. Geobot 36(2): 403-406. (in Polish with English summary)

GOS L., GOS K. 1993. New records of Orthodontium lineare (Musci, Bryaceae) in northern Poland. Fragm. Flor. Geobot 38(1): 325-327.

GÓRSKI P., URBAŃSKI P. 2004. Mszaki (“Bryophytes”). In: Kluza-Wieloch M., Janyszek S., Jurczyszyn M., Klimaszyk P., Klimko M., Nowiński M., Staniszewski R., Janyszek M., Urbańska M., Węgiel A. Waloryzacja przyrodnicza użytku ekologicznego "Wilczy Młyn" (Nature of protected area "Wilczy Młyn"), Poznań, pp 30-35 (in Polish - mskr.)

HASSEL K., SÖDERSTRÖM L. 2005. The expansion of the alien mosses Orthodontium lineare and Campylopus introflexus in Britain and continental Europe. J. Hattori Bot. Lab. 97: 183-193.

HEDENÄS L., HERBEN T., HAKAN R., SÖDERSTRÖM L. 1989. Ecology of the invading moss species Orthodontium lineare in Sweden: substrate preference and interactions with other species. J. Bryol. 15: 565-581.

HERBEN T. 1987. The ecology of the invasion of Orthodontium lineare Schwaegr. in central Europe. Symposia Biologica Hungarica 35: 323-333.
HERBEN T. 1990. Sociology of communities invaded by Orthodontium lineare (Bryophyta) in Europe (excl. the British Isles). Preslia 62: 215-220.

HERBEN T. 1994. Local rate of spreading and patch dynamics of an invasive moss species Orthodontium lineare. Journ. Bryol. 18: $115-125$.

KONSTANCIAK J. 2002. Mszaki zachodniej części obwodu ochronnego Wypalanki w Wielkopolskim Parku Narodowym (studium florystyczno-ekologiczne) ("Bryophytes of the western part of protected area "Wypalanki" in the Wielkopolski National Park (floristical-ecological study)"). Mskr. of the master thesis, Adam Mickiewicz University, Department of Geobotany. (in Polish)

LISOWSKI S., URBAŃSKI P. 1989. Campylopus introflexus (Hedw.) Brid. - nowy gatunek dla brioflory polskiej (Campylopus introflexus (Hedw.) Brid. - a new species for Polish bryoflora. Bad. Fizjogr. Pol. Zach. Ser. B 39: 181-183. (in Polish with English summary)

MATUSZKIEWICZ W. 2001. Przewodnik do oznaczania zbiorowisk roślinnych Polski ("Guide-book for vascular plants communities in Poland"). Vademecum Geobotanicum. Wyd. Nauk. PWN, Warszawa.

MEUSEL H. 1943. Vergleichende Arealkunde. I. Verl. Gebr. Borntraeger, Berlin-Zehlendorf.

MINDUR M. 1998. Mszaki obwodu ochronnego Osowa Góra w Wielkopolskim Parku Narodowym (studium florystycznoekologiczne) ("Bryophytes of the protected area "Osowa Góra" in the Wielkopolski National Park (floristical-ecological study)"). Mskr. of the master thesis, Adam Mickiewicz University, Department of Geobotany. (in Polish)

OCHYRA R. 1982. Orhodontium lineare Schwaegr. - a new species and genus in the moss flora of Poland. Bryol. Beitr. 1: 23-36.

OCHYRA R. 1983. Mchy synantropijne ("Synanthropic mosses"). Wiad. Bot. 27(1): 31-44. (in Polish)

OESAU A. 2002. Phascum leptophyllum Mull.Hal. ein Neuburger der rheinhessischen Akermoosflora. Limprichtia 20: 117$-127$.

RAZGULYAEVA L. V., NAPREENKO M.G., WOLFRAM CH., IGNATOV M. 2001. Campylopus introflexus (Dicranaceae, Musci) - an addition to the moss flora of Russia. Arctoa, a Journal of Bryology 10: 185-188.

RUSIŃSKA A. 2003. Mszaki użytku ekologicznego "Darzybór" ("Bryophytes of the protected area "Darzybór"). In: WrońskaPilarek D., Danielewicz W., Gałązka S., Gołdyn R., Gornowicz R., Kepel A., Maciorowski G., Mizera T., Pilarek Z., Rusińska A, Stasik L. 2003. Waloryzacja przyrodnicza użytku ekologicznego "DARZYBÓR" ("Nature of the protected area "Darzybór"). (in Polish - mskr.)

RUSIŃSKA A., URBAŃSKI P. 1993. Nowe stanowiska Orthodontium lineare Schwaegr. i Campylopus introflexus (Hedw.) Brid. na Pomorzu Zachodnim (New localities of Orthodontium lineare Schwaegr. and Campylopus introflexus (Hedw.) Brid. in the Western Pomerania). Bad. Fizjogr. Pol. Zach. Ser. Botanica 42: 225-227. (in Polish with English summary)

SÖDERSTRÖM L. 1992. Invasions and range expansions and contractions of bryophytes. In: J.W. Bates, A.M. Farmer (eds) Bryophytes and lichens in a changing environment. Oxford University Press, str. 131-158.

STEBEL A. 1994. Two neophytic mosses in southern Poland. Fragm. Flor. Geobot. 39(2): 672-673.

STEBEL A. 1995. Campylopus introflexus (Musci, Dicranaceae) found in the Carpathians. Fragm. Flor. Geobot. 40(2): 909-911.

STEBEL A. 1997. Mszaki Rybnickiego Okręgu Węglowego (Bryophytes of the Rybnik Coal Region). Fragm. Flor. Geobot. Ser. Polonica 4: 121-233. (in Polish with English summary)

STEBEL A. 2002. Materiały do brioflory Parku Narodowego Bory Tucholskie (Pomorze Zachodnie) ("Contribution to the bryoflora of the Bory Tucholskie National Park (Western Pomerania)"). Par. Nar. Rez. Przyr. 21(2): 159-175. (in Polish) 
STEBEL A., FOJCIK B. 2005. Kolejne stanowiska Campylopus introflexus (Bryopsida, Dicranaceae) w województwie śląskim ("Further localities of Campylopus introflexus (Bryopsida, Dicranaceae) on the area of Sląsk Province"). Fragm. Flor. Geobot. Ser. Polonica 12(2): 412-414.(in Polish)

STEBEL A., WIERZCHOLSKA S., PLAŠEK V., STANIASZEK M. 2005. New stations of Orthodontium lineare (Orthodontiaceae, Bryopsida) in the south-western Poland. Acta Bot. Siles. 2: $167-172$.

STEFAŃSKA E., STANIASZEK M., WIERZCHOLSKA S. 2006. Nowe stanowiska Campylopus introflexus (Musci, Dicranaceae) w południowo-zachodniej Polsce ("New stations of Campylopus introflexus (Musci, Dicranaceae) in south-western Poland"). Fragm. Flor. Geobot. Polonica 13(1): 224-227. (in Polish)
SZCZEPAŃSKI M. 2007. Mchy młodoglacjalnych pojezierzy przewodnik sesji terenowych warsztatów briologicznych ("Bryophytes of young-glacial lakelands - guide to field bryological workshops"). Welski National Park, Jeleń. (in Polish)

TOKARSKA-GUZIK B. 2005. The establishment and spread of alien plant species (Kenophytes) in the flora of Poland. Wyd. Uniwersytetu Śląskiego, Katowice.

URBAŃSKI P. 1994. Nowe stanowisko mchu Campylopus introflexus (Hedw.) Brid. na Pomorzu Zachodnim (New locality of moss species Campylopus introflexus (Hedw.) Brid. in the Western Pomerania). Bad. Fizjogr. Pol. Zach. Ser. Botanica 43: 191-192. (in Polish with English summary) 